\title{
Ferdinand Bauer or Johann and Joseph Knapp? A rectification
}

\author{
C. Riedl-Dorn ${ }^{1} \&$ M. Riedl ${ }^{2}$ \\ Archive for the History of Sciences, \\ Natural History Museum Vienna \\ Burgring 7, A 1010 Vienna, Austria \\ ${ }^{1}$ christa.riedl-dorn@nhm-wien.ac.at \\ ${ }^{2}$ mario-dominik-riedl@nhm-wien.ac.at
}

\begin{abstract}
The first part of the following paper deals with the life, travels, professional career as a natural history painter, use of colour charts and heritage of Ferdinand Bauer. The use of Ferdinand Bauer's colour chart(s) by other painters is also discussed. It is followed by a short history of the use of colour charts. The final part discusses the attribution of watercolours preserved at the Vienna Natural History Museum that have hitherto been ascribed to Ferdinand Bauer. They are compared to pictures at the Austrian National Library, at the Museum of Applied Arts in Vienna and at the Museum für Kunst und Gewerbe in Hamburg that were produced by Joseph Knapp and should be attributed to him using evidence from the use of specific paper and some technical details.
\end{abstract}

Keywords. Australia, Austria, botanical illustration, colour, Schönbrunn Gardens

\section{A short summary of Ferdinand Bauer's life and achievements}

Ferdinand Lucas Bauer was born the fifth son of seven children to Lucas and Theresia Bauer (née Hirsch) on January 20, 1760 at Feldsberg in northern Lower Austria (since 1920 known as Valtice in southern Moravia, a part of the Czech Republic). His father, Lucas Bauer, was Prince Josef Wenzel von Liechtenstein's court painter in Feldsberg from 1744 onwards. He mainly painted pictures for altar panels. Two of Ferdinand's brothers, Josef Anton and Franz Andreas, were also involved in painting. Lucas Bauer died in 1762 when Ferdinand was still a small child. His widow, who did not remarry, brought up the children and initiated Ferdinand in pencil drawing. The boy copied birds and plants from the designs of his father. At that time colouring and copying were considered a good occupation for children and were part of the Austrian primary school curriculum. Children, especially orphans, often used to colour maps and even botanical illustrations (Adelung, 1776; Krünitz, 1793). To ensure that the maps were correctly coloured by the children, a number corresponding to a colour shade was noted on the area to be coloured (Krünitz, 1793). The brothers were acquainted with botany and the art of botanical illustration through Norbert Boccius (1729-1806), the prior of a monastery at Feldsberg and a well-known physician and botanist at that 
time. A collection of botanical illustrations, the Codex Liechtenstein, commissioned by Boccius and consisting of 2748 miniatures, was executed by, amongst others, the three brothers (Lack, 2000). Ferdinand was only 15 years old when he started work on it. This early work shows the first examples of what seems to be colour code, in this case fewer than 150 numbers. Each number seems to be a reference to a colour in a colour chart. Following the family's arrival in Vienna, Boccius introduced Ferdinand Bauer to the famous Professor of Botany and Chemistry at the University of Vienna and Director of the Botanical Gardens, Nicolaus J. von Jacquin (1772-1817). He lived in the botanist's house and contributed a number of pictures to Jacquin's magnificently illustrated books. Jacquin employed numerous painters to create the illustrations for his exquisite works, and encouraged the painters to paint accurately from nature without any artistic decorative devices. Together with other painters, the Bauer brothers, who were trained in this type of painting by Boccius and their mother, were now employed by Jacquin to create illustrations of new and rare plants for his Icones Plantarum Rariorum (1781-1793). Later, Boccius and Jacquin introduced Ferdinand Bauer to the then Sheradian Professor of Botany at Oxford University, John Sibthorp (1756-1796), who visited Vienna in 1785. Bauer accompanied Sibthorp on his journey to Italy, Sicily, Crete, Cyprus, the Aegean Islands, Istanbul and western Anatolia, returning by way of Athens and Athos in 1786. During the expedition, Bauer created only pencil sketches on which he wrote a numeric code.

During his journey to the Levant, the numbers he noted on his drawings increased from roughly 150 to over 250 (Lack \& Mabberley, 1999). Bauer went back to England with Sibthorp where he finished his work on the Flora Graeca. It was Sir Joseph Banks who recommended Ferdinand Lucas Bauer to the British Admiralty as Natural History Painter for the second Flinders Expedition to Australia (18021805). Ferdinand Bauer was 41 years old when he climbed aboard the 'Investigator' as "Natural History Painter". As in the previous expedition with Sibthorp, Bauer's drawings were executed in pencil and the various colours noted in a numerical code. The number he used for designating colours increased from 250 to over 900 . Bauer returned to England in 1805, accompanied by 11 cases of drawings containing 1542 Australian plants, 180 Norfolk Island plants, and over 300 animals.

In August 1814, Ferdinand Bauer returned to Austria where he acquired a small house in Hietzing near Schönbrunn. He brought home a great number of drawings, as well as collections of plants and animals. The drawings and collections stayed with him until his death at Hietzing on March 17th 1826.

\section{Bauer's legacy}

At the auction following Ferdinand Bauer's death, Emperor Franz I (II) bought Bauer's drawings, 2249 in total, his herbarium, pelts of birds and mammals, insects, molluscs, etc. for the 'Vereinigte k. k. Naturalien-Cabinete' for a sum many times 
higher than the estimated price by the appraiser (Lack, 2003). Josef Natterer, curator at the 'Thiercabinet' (zoological collections) compiled detailed lists of the collection, especially of birds and mammals. According to him, 114 birds from Australia, Norfolk Island and Cayenne were acquired for the museum, of which 81 are still present in the ornithological collection (the collections and unpublished resources used in this paper are listed in Appendix 1). Ninety-eight of these 114 were still unidentified at the time of acquisition. Natterer eliminated 13 specimens as worthless due to damage or for other reasons. As the birds were not supplied with either note or labels giving the date and place of collection, the drawings supplied with these data had to be consulted. In some pictures it is evident that they had been prepared from dermoplastics. August von Pelzeln described a new species of parrot (Nestor norfolcensis) from a sketch by Bauer and from a coloured drawing, which was produced by the animal painter Theodor Franz Zimmermann (1808-1880) at the behest of Pelzeln in 1860 (Fig. 1 \& 2 ). Due to its poor condition, the only specimen of the bird at the Naturalien-Cabinete was removed from the collections before 1830 (Pelzeln, 1860). In the description, Pelzeln (1860) describes not only the bird but also the sketches made by Bauer "Sie sind mit Bleistift entworfen und die Färbung ist mit grossem Fleisse durch Nummern und Buchstaben bezeichnet, welche sich auf eine sehr ausführliche, die kleinsten Nüancen berücksichtigende Farbentabelle beziehen." ["They were drawn with lead pencil and the colouring is meticulously noted with numbers and letters that refer to a very detailed and finely nuanced colour table.'] (Pelzeln, 1860).

In this publication and in the 'Annalen des k.k. Naturhistorischen Museum Vol. 3' (Pelzeln \& Lorenz von Liburnau, 1888), Pelzeln states that Zimmermann's watercolour was based on the pencil sketch of Ferdinand Bauer and that Zimmerman used the 'Bauer'sche Farbtabelle' (Bauer's colour table) to accurately reproduce the colours of Nestor norfolcensis. The colour table enabled Zimmermann to finish Bauer's work some 34 years after the original painter's death. The artists commisioned by the 'Naturalien-Cabinet' produced most of the paintings directly in the collections at the Josephs Platz (Riedl-Dorn, 2019). The 'Naturalien-Cabinet' is probably the last known location of the colour table used by Bauer. The colour charts might have been lost during the shift of the collections of the Naturalien Cabinete from the Josephs Platz to the Natural History Museum. In 'Copie. Verzeichniß der in dem bauerschen Herbario befindlichen Pflanzenarten' (Copy. Register of the plant species contained in Bauer's herbarium), Leopold Trattinick, the curator of botany since 1807, mentions the acquisition of herbarium specimens: "Planzen angeblich 3339" [plants allegedly 3339] and adds: "Von botanischen Handzeichnungen aus Ferd. Bauers Nachlasse sollen sich finden.......1876" ["from botanical hand drawings in the legacy of Ferdinand Bauer there are supposed to be.....1876"] (Riedl-Dorn, 1989).

The discrepancy between the alleged number of 1876 drawings and the larger number of images that was found can be explained as follows. During Trattinick's time, 55 drawings had been listed as missing. Leopold Trattinick's successor was Stephan Ladislaus Endlicher, one of the foremost botanists of his time. Endlicher sent 
Bauer sketches to botanists e.g. F.A.W. Miquel, C. Schauer, J. Lindley, G. Bentham, and had copies made by painters (Riedl-Dorn, 2019). Eduard Fenzl, who succeeded Endlicher, followed Endlicher's example and would send sketches to botanists and had copies made (letter from Fenzl to Bentham 2nd July 1865 and letter to Bentham dated after 1870, the latter included a tracing of a Bauer drawing, Royal Botanical Garden Kew, Archives Inv. Nr. 1370). The copies and tracing were integrated into the Bauer collections and were later attributed to Bauer. This explains why the number of drawings increased from 1876 around 1826 to 1970 in 1885 (Günter Beck von Managetta inventory of the Botany collection 1885).

\section{Some notes on the history of colour charts used by artists and scientists}

Although Ferdinand Lucas Bauer was certainly the most profilic user of colour codes, he was not the only artist to do so. The Renaissance painters Hans Burgkmair the elder (1473-1531) and Albrecht Dürer (1471-1528) noted information about colours on their sketches, Burgkmair used abbreviations like the letter "g" for Gelb (= yellow) (Schilling, 1933), whereas Dürer wrote the whole word. Neither of them used a colour chart or table as reference. The first published numbered colour charts appear in textbooks for miniature painters at the end of the 17th century. One of the earliest examples of such a textbook was published in Middleburgh by Brugge around 1665, with a second edition published in 1670 (Brugge, 1670). Seven years later the first German edition appeared (Brugge, 1677). In the second half of the 18th century, natural sciences, as well as proceedings for manufacturing various articles, required some kind of standardisation in regard to reproducibility of colours among other data. This was especially important for porcelain and tapestry manufacturers, who were among the first to create colour tables for the purpose of standardisation. The tables were often numerical and included samples of colours. The painters, who worked for the manufacturers, were taught at the art academies to use colour charts. During the late Baroque and the Biedermeier, pictures of flowers were requested frequently and a fairly small number of flower and botanical painters provided the manufacturers with templates. It is most likely that these painters had to adhere to the manufacturers' specifications including the use of colour charts. It is important to note that the painters who worked for N.J. Jacquin were often trained at the 'Manufaktur Zeichenschule der Akademie / Manufacture drawing school of the Academy'. The Manufaktur Zeichenschule der Akademie was founded in 1758 as 'k.k. Commercial-Zeichnungs Academie' to train painters for businesses. The curriculum included amongst other things flower painting. The scientific circle around Jacquin was very interested in creating colour standards for scientific uses. Giovanni Antonio Scopoli (1723-1788), who was the successor to N.J. Jacquin at the Bergbauakademie in Chemnitz (mining academy in Banská Štiavnica), and the Jesuit priest, mineralogist and entomologist Nikolaus Poda von Neuhaus (1723-1798), who was also a professor at the mining academy, developed a colour system which was 


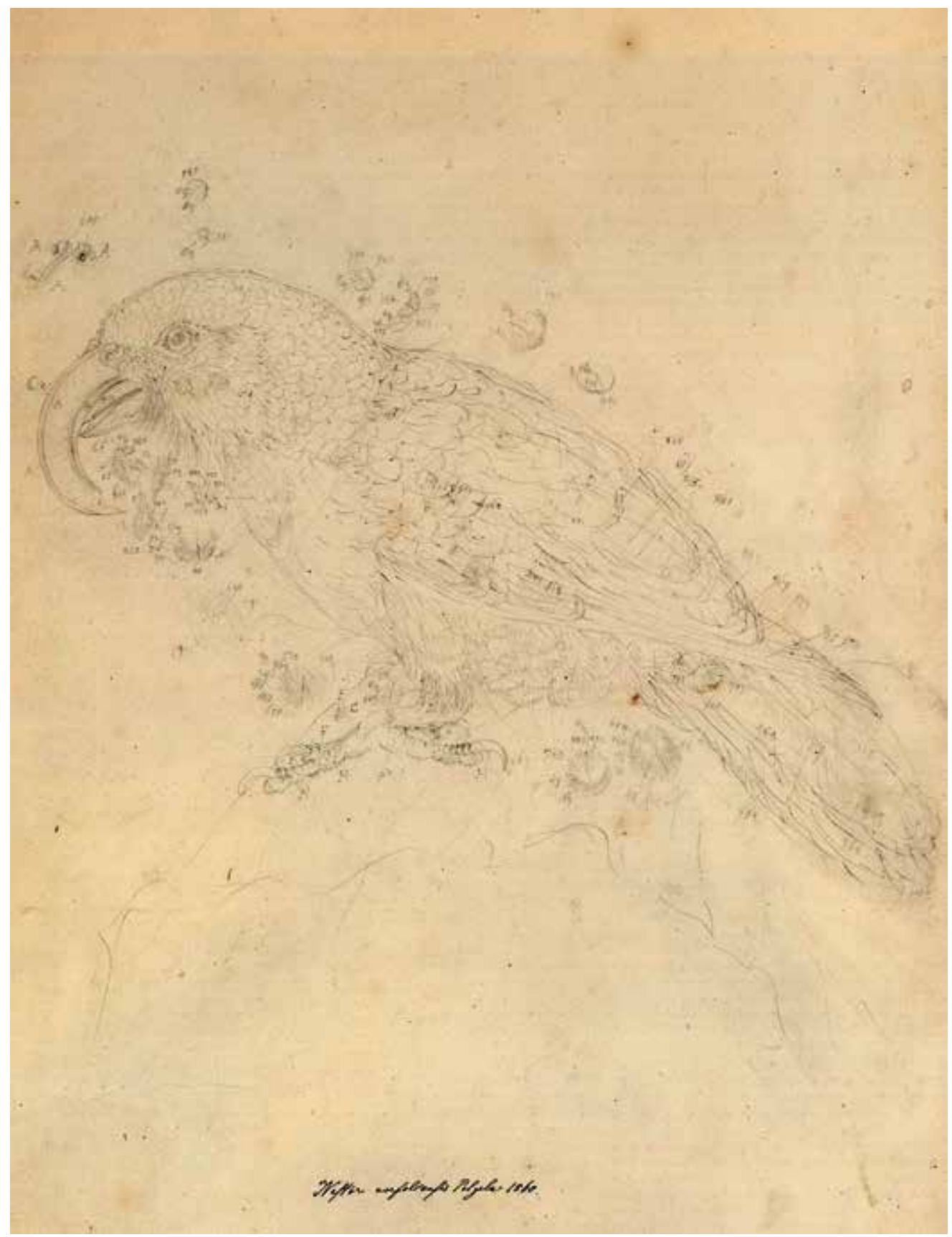

Fig. 1. Ferdinand Lucas Bauer, Nestor norfolcensis, pencil drawing, Norfolk Island, 1805, reproduced with permission from the Natural History Museum Vienna. 
published in 1763 (Karliczek, 2016). The entomologist and botanist Jacob Christian Schaeffer (1718-1790) published a booklet which included a numbered colour chart as an example for the proposed system (Schaeffer, 1769).

Though not without flaws, the books were very influential and important to the development of colour charts and a standardisation of colour nomenclature, and served as a blueprint for other authors. Schaeffer noted that he had initially planned to restrict the book to the field of entomology (Nickelsen, 2006). Schaeffer and Jacquin were also acquainted and in frequent contact. The Archives for the History of Sciences in Vienna has 59 letters from Schaeffer to Jacquin. Another acquaintance of Jacquin's, the botanist, entomologist and teacher Johann Ignaz Schiffermüller (1727-1806) (Lack, 2008) developed a colour system which was intended for the correct descriptions of the colours of nature. Schiffermüller proposed the use of a colour wheel and a chart (Schiffermüller, 1772). The colours in the chart were arranged by letters instead of numbers. The German mineralogist Abraham Gottlob Werner (1749-1817) developed a colour nomenclature for mineralogy (Werner, 1774), largely based on Schaeffer's work. While Schaeffer's work fell into disuse, Werner's colour system was widely adopted by other mineralogists and even zoologists. Werner's work also served as the base for the only colour chart that was proven to have actually been used by Ferdinand Lucas Bauer. The first volume of Estner (1794) included four colour charts, which were used by Ferdinand Lucas Bauer during his stay on Norfolk Island (August 1804 to February 1805) (Riedl-Dorn et al., 2014). Twelve years earlier, in 1782, the German philosopher, art theorist and educator Christian Friedrich Prange had published the hitherto most complete colour reference system (Prange, 1782). His Farbenlexicon was based on Schaeffer's Farbenverein and included 4608 numbered colour samples that were arranged in 46 tables. Each table contained 96 colour shades (Karliczek, 2016).

In his book, Prange (1782) also explains how to use the colour tables for drawing insects, flowers, plants and landscapes. After drawing the desired subject, the artist was supposed to compare the colour of the subject with the colour table and note the corresponding number in the drawing. This description closely matches Ferdinand Bauer's working method (Lack, 2016). Prange's colour charts were used as a reference in books on minerals, geology, lichens and dyeing. Later, an improved version of Prange's Farbenlexicon was published in Vienna (Anonymous, 1794). Although the anonymous authors claimed that the book included 5000 colour samples, the work only contains 4608 samples (Karliczek, 2016). Some of the improvements over the Farbenlexicon were more detailed information about the application and the mixture colours, and the colours were no longer painted into the chart, which can cause variations from book to book, but were painted on a large sheet of paper that was cut into strips and glued into the chart.

The first published colour chart explicitly designed for Botany appeared in Willdenow (1792). Willdenow (1765-1812), like Linnaeus, doubted the usefulness of information on colour in the description of plants and felt that colour was only 


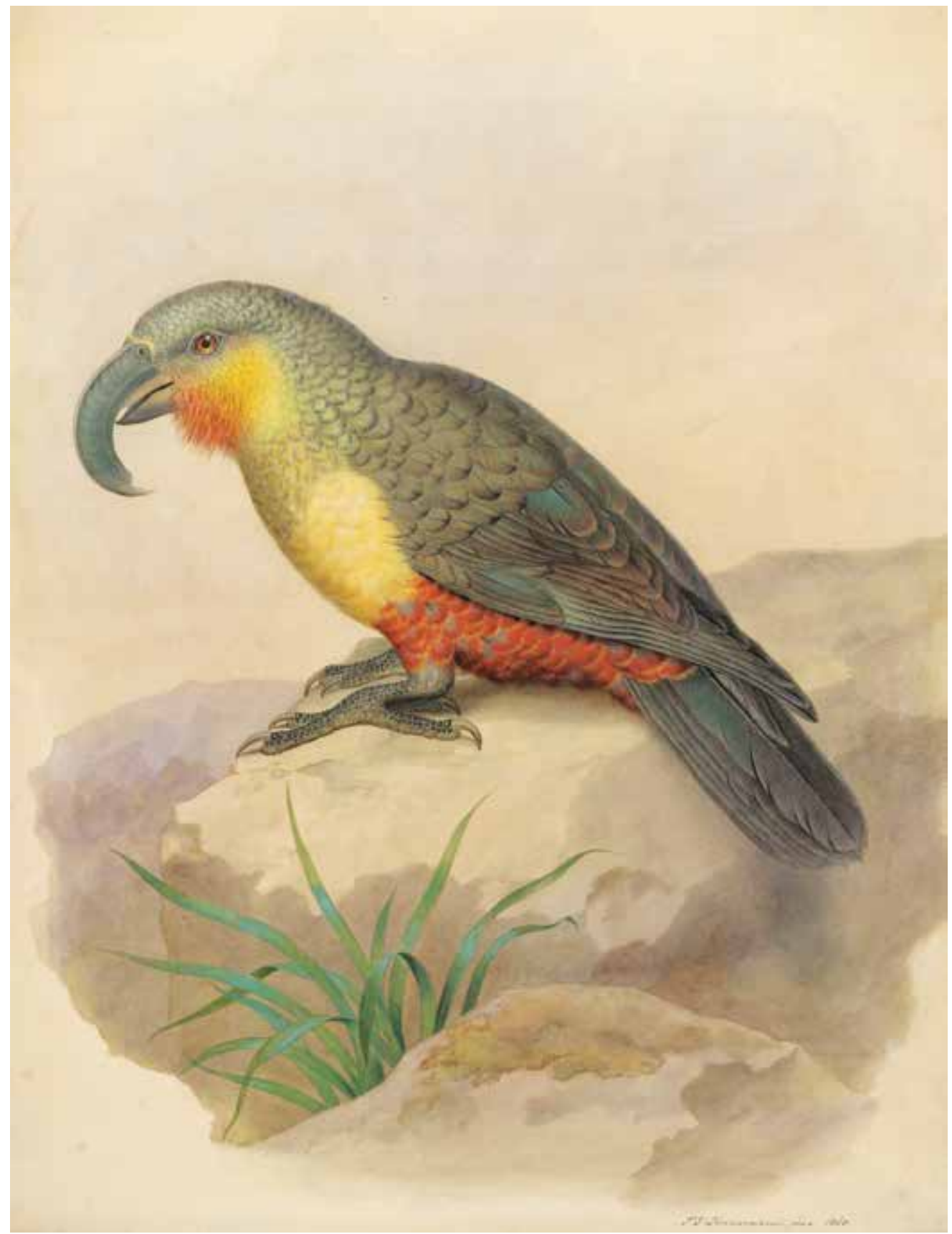

Fig. 2. Theodor Franz Zimmermann, Nestor norfolcensis based on drawing by F.L. Bauer, watercolour, Vienna, 1860, reproduced with permission from the Natural History Museum Vienna. 
useful in the description of lichens and fungi (Kaliczek, 2013). Willdenow's chart was supposed to be used for the descriptions of fungi and lichens and only included a limited number of colours. Today more than ever artists and scientists rely on colour scales and colour tables for their work. Colour systems like Pantone, the RAL scale and the html colour code are modern interpretations of the tables and charts used by artists and scientists of centuries past.

\section{Discussion of attribution}

Among the more than 2000 drawings in the Ferdinand Lucas Bauer collection of the Archives for the History of Sciences, 60 were executed in colour. The coloured drawings are kept in a historical folder labelled 'Flora Austriaca 1832 Pictore Ferdinand Bauer'. The reference to Ferdinand Bauer was added at a later date in a different handwriting. The images show cultivated plants and fruits.

Because of differences in style and composition compared to other known examples of Bauer's work, attribution of the only coloured paintings in the Ferdinand Lucas Bauer collection of the Archives for the History of Sciences have been in doubt for quite some time - rightfully so as new research has proven that the 60 coloured drawings and watercolours were not painted by Bauer but by Joseph Knapp (18101867). Joseph Knapp's father, Johann Knapp (1778-1833), might have produced two of the paintings, Punica granatum L. (branch \& inflorescence) and fruit of Cydonia oblonga Mill. The label on the folder suggests that the paintings were created around 1832, a few years after Ferdinand Lucas Bauer's death in 1826. Bauer's illustrations were lauded for their lack of artistic embellishment such as overlapping stems and branches, especially in the work created after the Codex Liechtenstein. Bauer's work is defined by a very clear and clean representation of the various parts of the plants or animals. Common to many of the watercolours are overlapping stems and branches, and on some of them added details such as water droplets.

Because of strong similarities with flower paintings created by Johann Knapp shown at the exhibition 'Blumen für das Kaiserhaus' at the Vienna Belvedere in 2006, and the Knapp images in the collections of the Museum for Kunst und Gewerbe in Hamburg, the possibility that Johann Knapp produced the watercolours in the Archives for the History of Sciences collection was considered.

\section{Johann and Joseph Knapp}

Johann Knapp and his son were court painters for the Archdukes Anton Viktor and Johann. A child prodigy, Johann Knapp started his academic training as a flower painter at the Akademie Zeichenschule at the age of 13. At that time Knapp had already been working for three years as a trainee at a tapestry manufacturer before he was discovered 
by a clergyman who paid for his education at the academy. Archduke Anton Viktor commissioned Knapp to paint the plants in the imperial garden at Schönbrunn. To facilitate the task, the painter was given an apartment in Schönbrunn close to where Ferdinand Lucas Bauer was living. Joseph Knapp followed in his father's footsteps and continued to draw and paint the plants at the imperial garden. He was trained by his father and later attended the flower painting class at the academy of fine arts. Johann Knapp's best-known painting 'Homage to Jacquin' or 'Jacquin's Monument' was commissioned in 1821 on the occasion of the 4th anniversary of the famous botanist's death. Joseph Knapp, who was 11 years old at the time, helped his father with the painting. Joseph Knapp was not only a painter but was also trained as a botanist by Endlicher for whom he also produced paintings (Riedl-Dorn, 2019). The flower piece 'Homage to Jacquin' also included a depiction of a Bauera, named after Ferdinand and Franz Bauer, and a depiction of Rhynchoglossum obliquum Blume which was based on a sketch Bauer had created in Timor (Lack, 2015). Ferdinand Bauer and Johann Knapp were certainly more than simple acquaintances: according to Mabberley (2017), Bauer had asked Robert Brown to name the gesneriad genus Loxotis R.Br. ex Benth. (= Rhynchoglossum Blume) 'Knappia'after Knapp. Plant paintings by Johann and Joseph Knapp are kept in the collections of the Vienna Belvedere, the Albertina, the Austrian National Library, the Vienna Museum for Applied Art and the Museum für Kunst und Gewerbe in Hamburg.

\section{Description of the watercolours in the Archives for the History of Sciences}

With the exception of the watercolour of a branch of the inflorescence of Punica granatum and that of the fruit of Cydonia oblonga, all the drawings in the Flora Austriaca folder are framed by a single line pencil frame. The frame size is always the same and very likely shows the outline of a copper printing plate or was intended to simulate a printing plate. The corners of the frame are slightly rounded and the lines sometimes uneven: this rather indicates the use of an actual printing plate instead of a ruler to draw the lines. The corners of copper printing plates have to be slightly rounded so that the plate does not rip the damp paper during the printing process. On many of the pictures, there is a number written in pencil and often there is also a second Roman number written with ink on the frame under the penciled number. Below the frame there are often annotations on the plant's name and the month in which the flower was in bloom or the drawing was created. The annotations were probably added by Bredemayer, the director of the imperial garden. The two frameless watercolours are different from the others in the kind of paper that was used, as well as in the painting technique. The colour application is much thicker and opaque unlike the majority of the paintings where the colour is almost translucent and allows the viewer to see the underlying pencil drawing. Where a watermark could be found, all watercolours except for the two aforementioned were executed on the Dutch C[ornelius] \& I[an] 
Honig paper. The two exceptions were drawn on a heavier Whatman paper. Founded in 1690, C \& I Honig was one of the largest paper mills on the European continent and had a long tradition of producing high quality drawing and printing paper. Honig paper was often the paper of choice for printing important documents. Whatman Mills was founded in Kent in 1733 and quickly became one of the largest and most innovative paper mills. They are credited with the invention of vellum paper and with being the first steam powered paper mill. Many well-known artists worldwide used paper produced by Whatman Mills including Ferdinand Lucas Bauer and Johann Knapp.

\section{Comparison of the watercolours in the Archives for the History of Sciences with the paintings in other collections}

The watercolours at the National Library were produced between about 1833 and 1837 . Those labelled 'Flora Exotica' are bound in 4 volumes and largely follow the design and composition of those of the 'Flora Austriaca'. Each Volume contains 63 pictures. The title pages of the Flora Exotica Vols I - III show the names of the author and the artist. The author was the then director of the imperial garden Franz Bredemeyer (1758-1839), and the artist was Joseph Knapp. The title page of Vol. IV. only shows the author.

Unlike the coloured drawings at the Natural History Museum in Vienna, those of the Flora Exotica were, with a few exceptions, signed by the artist. Four drawings were produced by the animal painter Leopold Brunner jr (1822-1849). The Brunner drawings differ both in style as well in the choice of paper from the drawings produced by Joseph Knapp. Brunner used Whatman paper for his watercolours of Erica carnea L.

Apart from the Flora Exotica, the National Library also keeps a collection of eight boxes with about 149 watercolours of fruits, vegetables and ornamental plants that were painted by Joseph Knapp. The watercolours contained in the boxes again largely follow the design and composition of the Flora Austriaca watercolours. All drawings that could be attributed to Joseph Knapp and which had a watermark on the paper were drawn on C \& I Honig paper like the drawings at the Natural History Museum.

The Museum for Applied Arts (MAK) in Vienna also holds a collection of some hundreds of paintings of flowers and fruits by Joseph Knapp, which they acquired in 1879. The pictures largely follow the composition and design of the coloured drawings that are kept at the Natural History Museum Vienna and the Austrian National Library. The majority of the watercolours at the MAK were made on Whatman paper from 1830 . The drawings, which were probably produced after 1833 , were executed on C \& I Honig paper.

In 1896 the director of the Museum für Kunst und Gewerbe (MKG) in Hamburg, Julius Brinkmann, acquired 1151 paintings by Joseph and Johann Knapp for the 
museum's decorative art collection (de Cuveland, 2006). Among these pictures at least three contain elements of or are largely identical with the watercolours kept at the museum in Vienna. The attribution of the individual images kept at the MKG cannot be assigned with certainty, as they don't bear a signature and are very similar in style and composition. Identification of the painter based on watermarks or paper dates is also not always reliable, and furthermore not all the paper used had watermarks. It is very likely that the early papers, which could be identified as J. Whatman 1794 and 1804, John \& Hayes 1804 and Ruse \& Turner 1805 were used by the father, as they predate the son's birth by more than five years. The four watercolours from the Natural History Museum in Vienna are: XXXVI Punica granatum, XLIII Rosa lutea bicolor (a synonym of Rosa foetida Herrm.), XXIV Berberis vulgaris L., and XLVII Cytisus laburnum L.

The pomegranate painting in Hamburg shows a cut half of the fruit (on the right), that is identical to the cut half on the picture at the Natural History Museum in Vienna (Fig. $3 \& 4$ ). The Rose is identical except for a juvenile fruit that was added or removed, only the Vienna drawing has a juvenile fruit at the top of the plant (Fig. 5 \& 6). The drawings of the rose also have different titles: in Vienna it is named XLIII Rosa lutea bicolor and in Hamburg Rosa eglanteria variegata (now considered a synonym of Rosa rubiginosa L.). Berberis vulgaris and Cytisus laburnum are represented on two separate sheets in Vienna, on one and the same in Hamburg, but otherwise the pictures are identical (Fig. 7-9).

\section{Summary}

It is shown that Bauer's colour chart(s) continued to be used even after the artist's death and that it was located at the Natural History Museum's predecessor, the Zoologisches-Cabinet, until 1860. The current whereabouts of Ferdinand Lucas Bauer's colour chart(s) still remains a mystery. The question of attribution of the coloured drawings that have hitherto been attributed to Bauer is finally resolved. The close connection between Bauer and the elder Knapp, and the labelling on the folder, has led to an incorrect attribution for the coloured drawings at the archives. Although it was suspected that the older Knapp might have been the painter, the possibility that the younger Knapp might have been the creator has previously not been much considered.

DEDICATION. We dedicate this article to David Mabberley on his 70th birthday. His studies on the painter Ferdinand Lucas Bauer started more than 30 years ago, and he has published several books and articles about the Austrian natural history painter, mainly dealing with the botanical work and the colour code used by the artist. For his research on Bauer, David Mabberley visited the Herbarium and the Archives for the History of Sciences at the Natural History Museum in Vienna several times. His latest book Painting by Numbers also includes a great number of drawings from Vienna. 


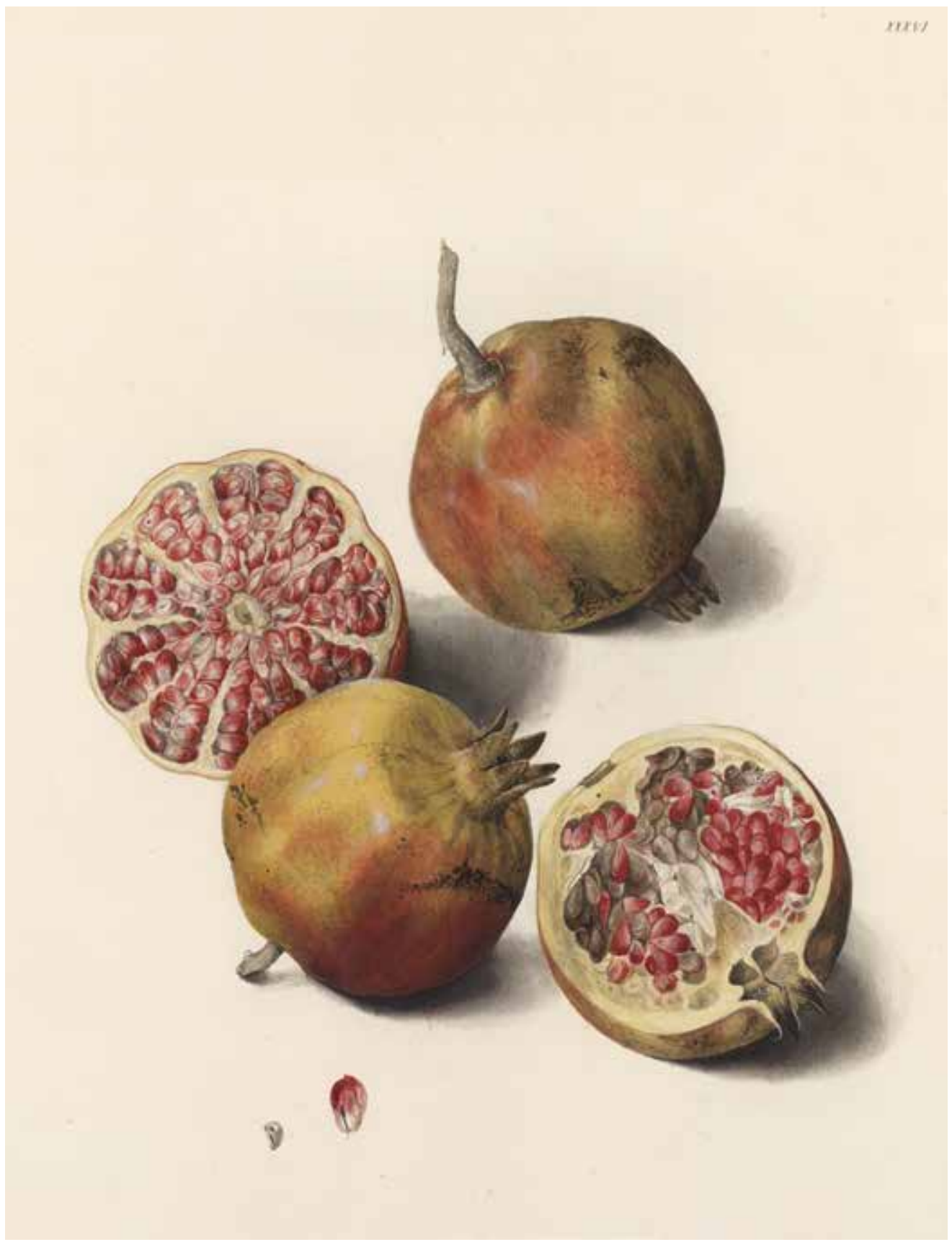

Fig. 3. Joseph Knapp, XXXVI Punica granatum, watercolour, Vienna, around 1832, Natural History Museum, Vienna, reproduced with permission from the Natural History Museum Vienna. 


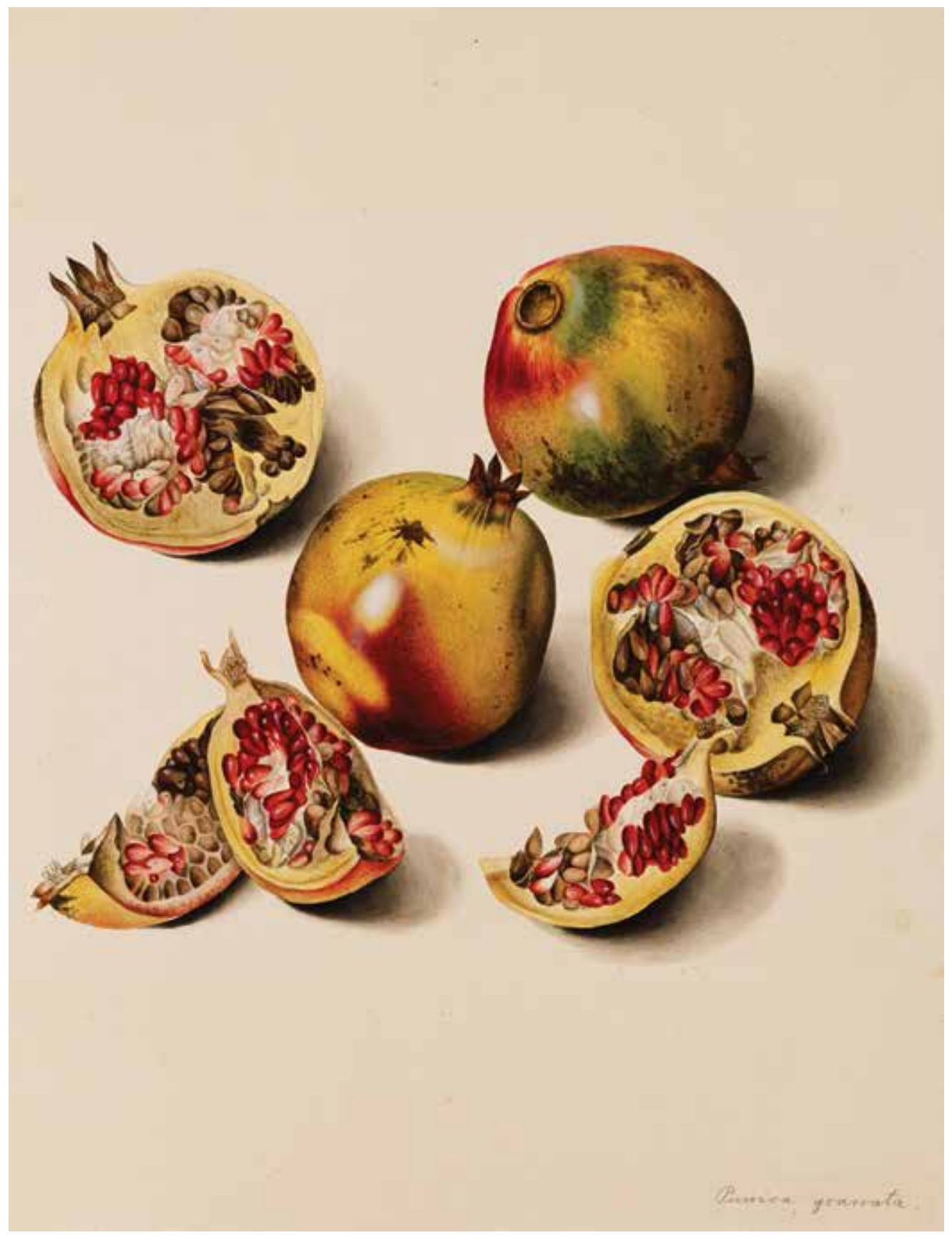

Fig. 4. Johann or Joseph Knapp, Punica granata [sic] (438), watercolour, Vienna, s.d., reproduced with permission from the Hamburg Museum für Kunst und Gewerbe. 


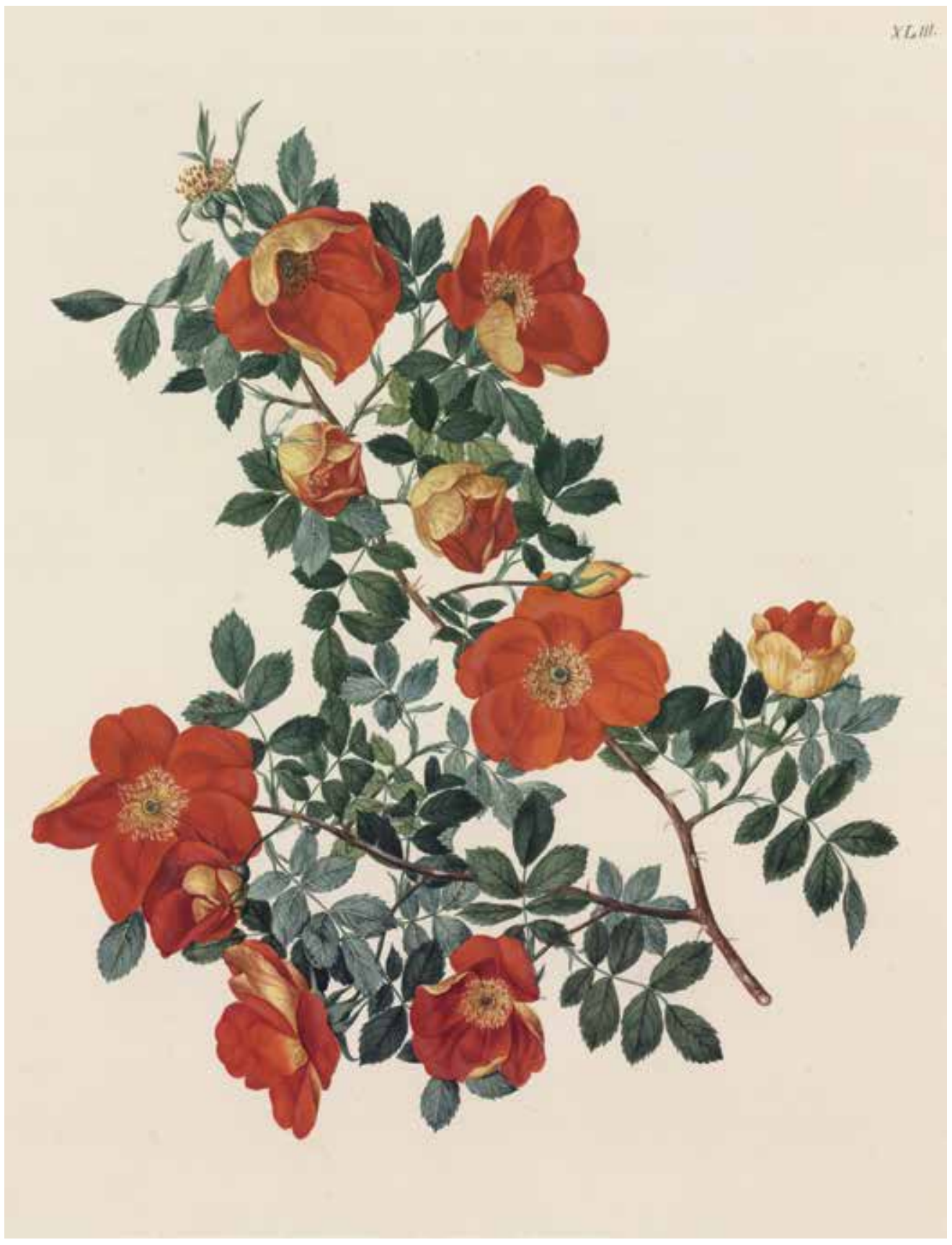

Fig. 5. Joseph Knapp, XLIII Rosa lutea bicolor (a synonym of Rosa foetida), watercolour, Vienna, around 1832, reproduced with permission from the Natural History Museum Vienna. 


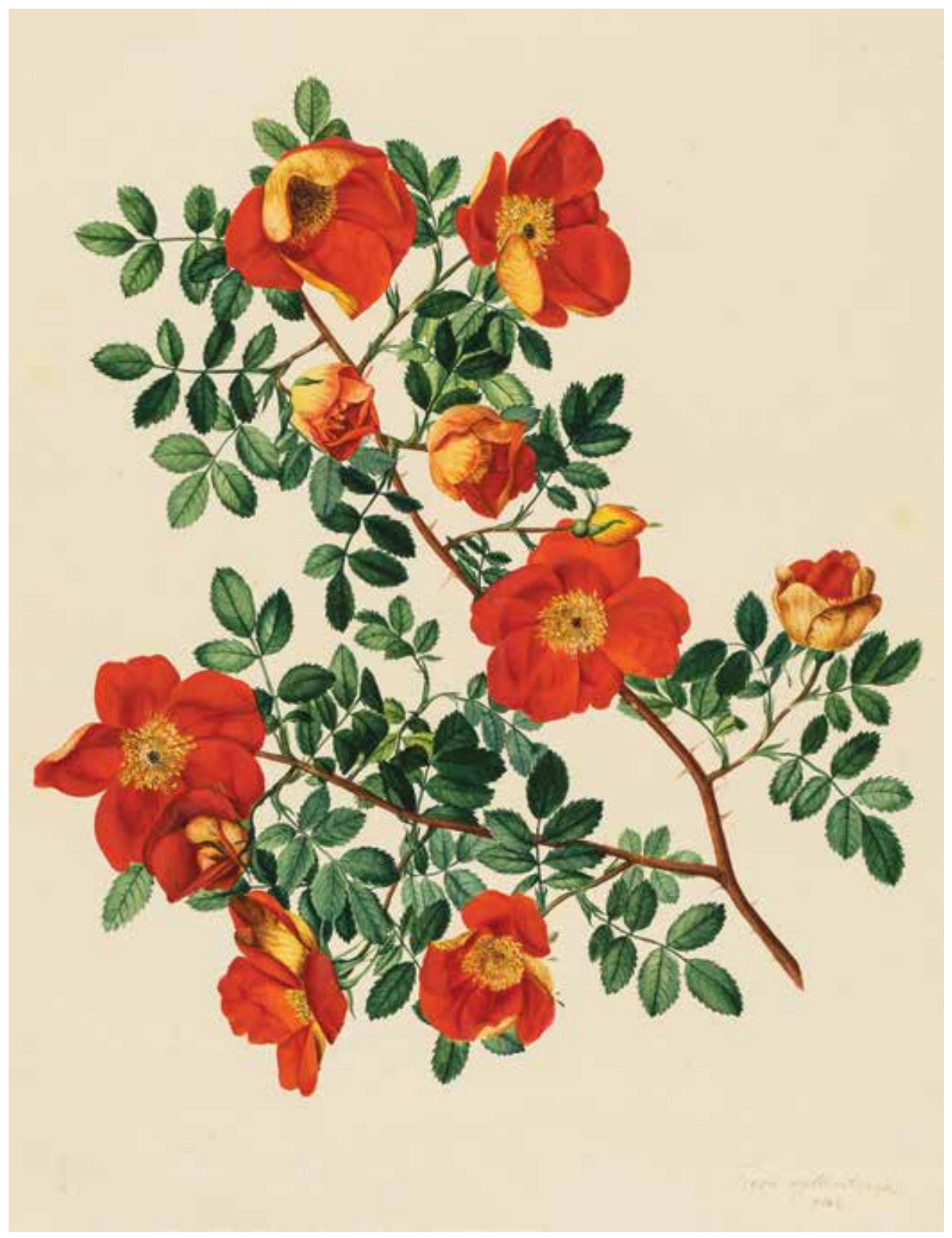

Fig. 6. Johann or Joseph Knapp, Rosa eglanteria variegata (a synonym of Rosa rubiginosa) (584), watercolour, Vienna, s.d., reproduced with permission from the Hamburg Museum für Kunst und Gewerbe. 


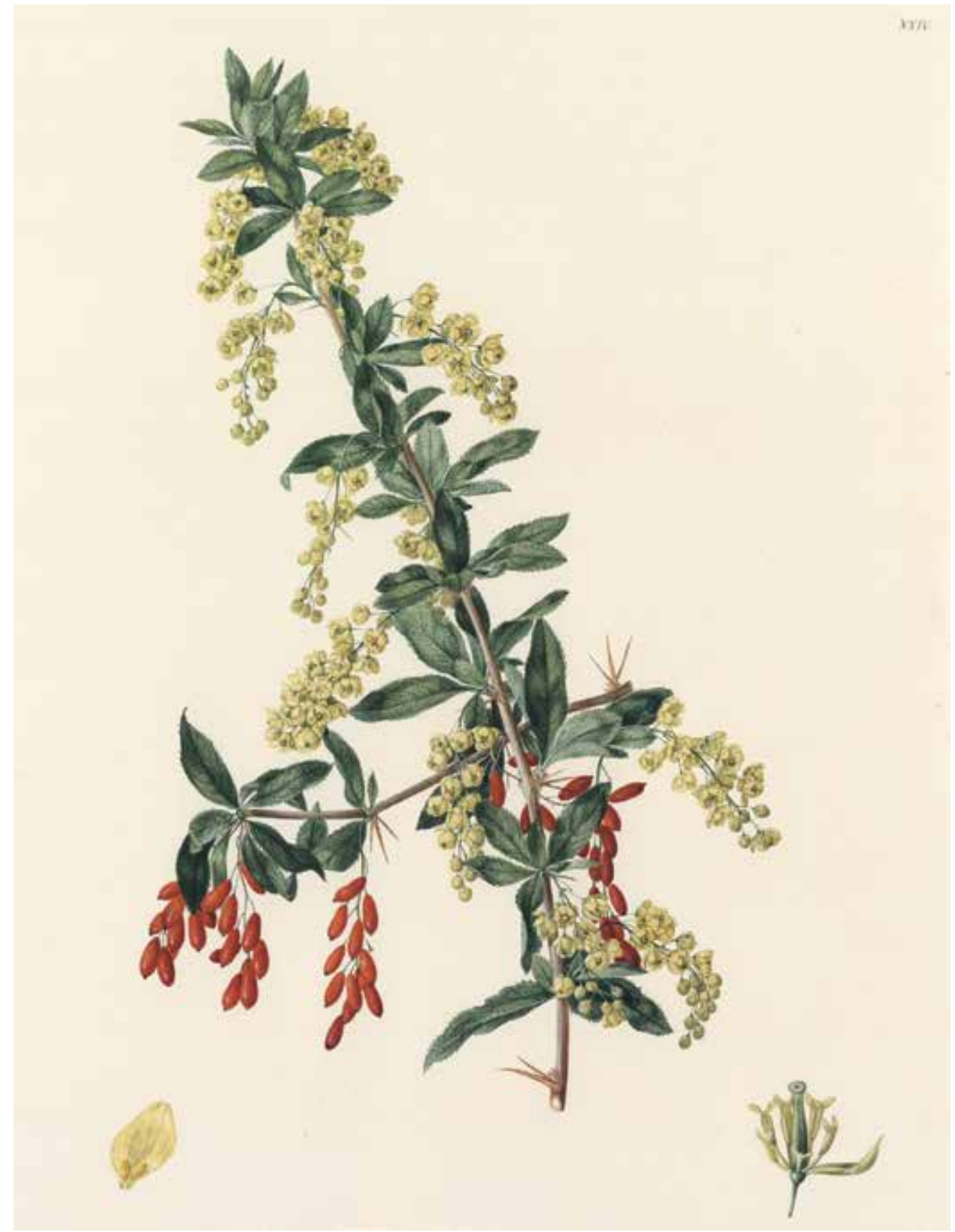

Fig. 7. Joseph Knapp, XXIV Berberis vulgaris, watercolour, Vienna, around 1832, reproduced with permission from the Natural History Museum Vienna. 


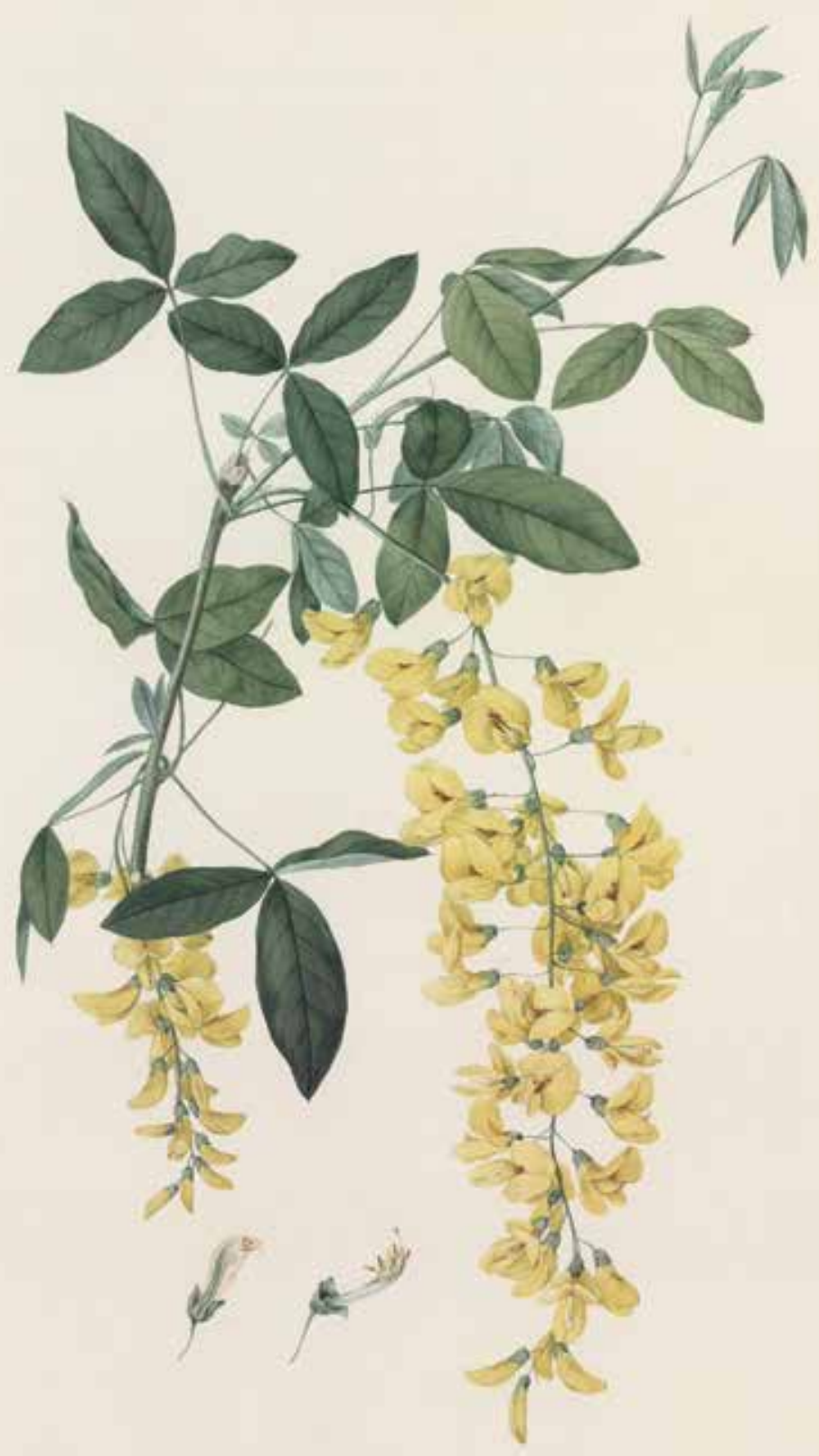

Fig. 8. Joseph Knapp, XLVII Cytisus laburnum, watercolour, Vienna, around 1832, reproduced with permission from the Natural History Museum Vienna. 


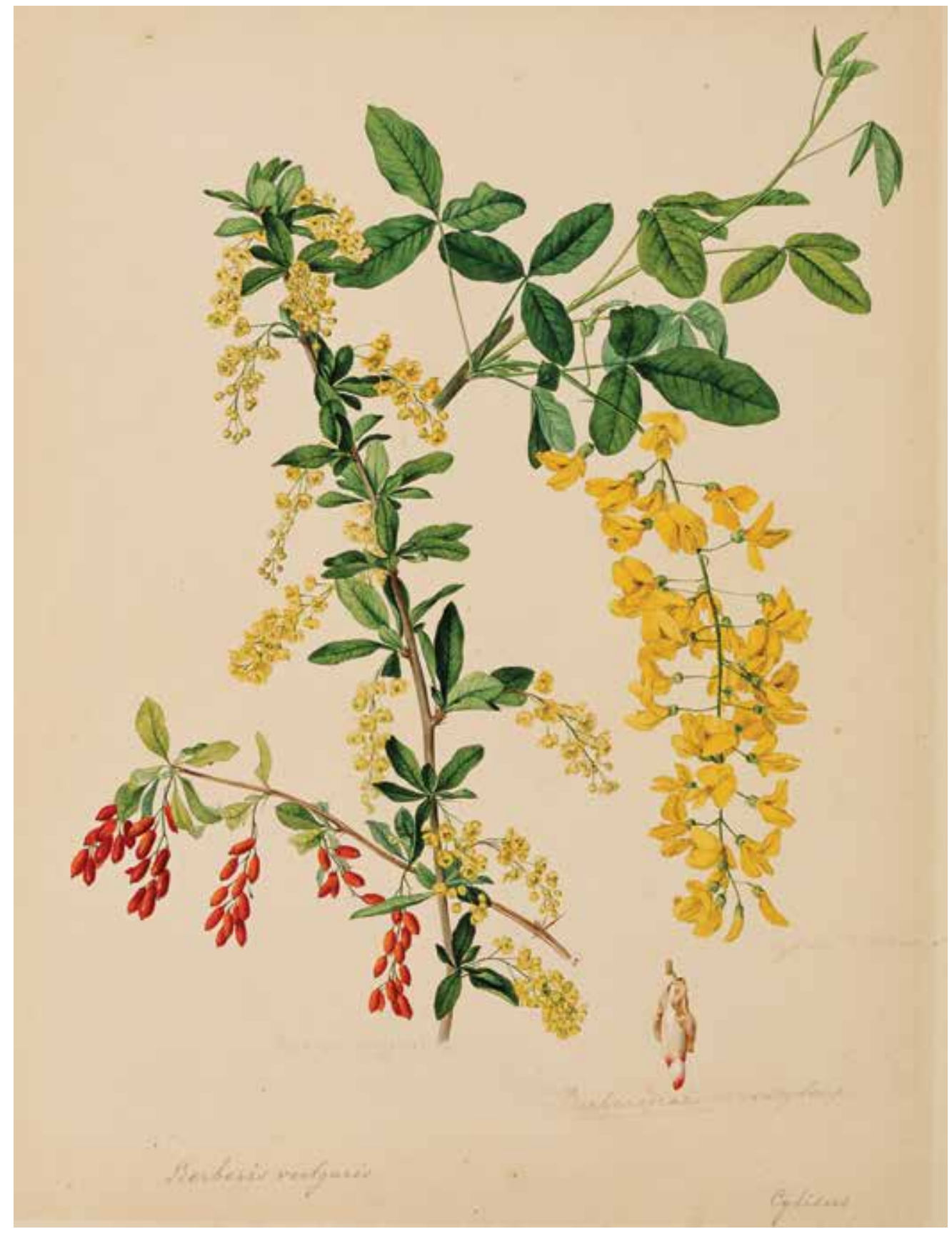

Fig. 9. Johann or Joseph Knapp, Berberis vulgaris and Cytisus laburnum (788), watercolour, Vienna, s.d., reproduced with permission from the Hamburg Museum für Kunst und Gewerbe. 


\section{References}

Adelung, J.C. (1776). Allgemeines Verzeichniß neuer Bücher - mit kurzen Anmerkungen. Nebst einem gelehrten Anzeiger, Auf das Jahr 1776. Leipzig.

Anonymous (1794). Wiener Farbenkabinet; oder vollständiges Musterbuch aller Natur-, Grund- und Zusammensetzungsfarben mit 5000 nach der Natur gemalten Abbildungen und der Bestimmung des Namens einer jeden farbe, dann einer ausführlichen Beschreibung aller Farbengeheimnisse. Vienna: Schönfeld.

Brugge, G. (1670). Verlichterie-Kunde, of recht gebruyck der Water-Verwen. In welcke des selfs kennis, en volkomen gebruyck tot de Schilder-Kunde, ende de Illuminatie ofte Verlichterie noodigh zijnde, kortelijck werden geleert. Middelburgh: Goeree, Wilhelmus.

Brugge, G. (1677). Illuminir oder Erleuchterey.Kunst/ Oder der Rechte Gebrauch der Wasserfarben darinnen derselbigen rechter Grund und vollkommener Gebrauch sowol zu der Mahlerey als Illuminirung und Erleuchterey kürzlich gezeiget wird. Hamburg: Naumanns Wolfgang \& Wolffens, Georg.

De Cuveland, H. (2006). Natur im Aquarell. Meisterwerke der Wiener Hofmaler Johann und Joseph Knapp. Munich, Berlin, London, New York: Prestel.

Estner, F.J.A. (1794). Versuch einer Mineralogie für Anfänger und Liebhaber nach des Herrn Bergcommissionsraths Werner's methode. Vienna: Jos. Georg Oehler.

Gräffer, F.A. \& Czikann J.J. (eds) (1837). Oesterreichische National-Encyklopädie, oder, Alphabetische Darlegung der wissenswürdigsten Eigenthümlichkeiten des österreichischen Kaiserthumes. Vienna: Beck.

Karliczek, A. (2013). Vom Phänomen zum Merkmal - Farben in der Naturgeschichte um 1800. In: Vogt, M. \& Karliczek, A. (eds) Erkenntniswert Farbe, pp. 83-111. Berlin, Jena: Institut für Geschichte der Medizin, Naturwissenschaft und Technik Friedrich Schiller Universität.

Karliczek, A. (2016). Wiener Farbenkabinet. In: Karliczek, A. \& Schwarz, A. (eds) Farre. Farbstandards in den frühen Wissenschaften, pp. 336-337. Jena: Salana.

Krünitz, J.G. (1793). Oeconomische Encyclopädie, oder allgemeines System der Land-Hausund Staats- Wirthschaft, und der Kunst-Geschichte in alphabetischer Ordnung. Berlin: Pauli.

Jacquin, N.J. (1781-1793). Icones plantarum rariorum I.-III. Vienna: A. König.

Lack, H.W. (2000). Ein Garten für die Ewigkeit. Der Codex Liechtenstein. Berne: Benteli.

Lack, H.W. (2003). Ferdinand, Joseph und Franz Bauer: Testamente, Verlassenschaften und deren Schicksale. In: Annalen des Naturhistorischen Museums Wien, vol. 104B, pp. 479-551. Vienna: Verlag des Naturhistorischen Museums in Wien.

Lack, H.W. (2008). Franz Bauer. Das gemalte Zeugnis der Natur. Vienna: Verlag des Naturhistorischen Museum Wien.

Lack, H.W. (2015). The Bauers Joseph, Franz \& Ferdinand: masters of botanical illustration. Munich, London, New York: Prestel.

Lack, H.W. (2016). Die Stenographie-Zeichnungen und Farbkodes der Brüder Bauer. In: Karliczek, A. \& Schwarz, A. (eds) Farre. Farbstandards in den frühen Wissenschaften, pp. 131-148. Jena: Salana.

Lack, H.W. \& Mabberley, D.J. (1999). The Flora Graeca story. Sibthorp, Bauer and Hawkins in the Levant. Oxford: Oxford University Press.

Mabberley, D.J. (2017). Painting by numbers: the life and art of Ferdinand Bauer. Sydney: University of New South Wales Press.

Nickelsen, K. (2006). Draughtsmen, botanists and nature: The Construction of EighteenthCentury Botanical Illustrations. Dordrecht. 
Pelzeln, A. von (1860). Nestor norfolcensis. In: Sitzungsbericht der Kaiserlichen Akademie der Wissenschaften, vol. XLI, p. 322. Vienna: Akademie der Wissenschaften Wien.

Pelzeln, A. von \& Lorenz von Liburnau, J. (1888). Typen der ornithologischen Sammlung des k.k. naturhistorischen Hofmuseums. IV. Theil. In: Annalen des Naturhistorischen Museums, vol. III, pp. 37-62. Vienna: Verlag des Naturhistorischen Museums Wien.

Prange, C.F. (1782). Farbenlexicon, worin die möglichsten Farben der Natur nicht nur nach ihren Eigenschaften, Benennungen, Verhältnissen und Zusammensetzungen, sondern auch durch die wirkliche Ausmahlung enthalten sind. Zum Gebrauch für Naturforscher, Mahler, Fabrikanten, Künstler und übrigen Handwerker, welche mit Farben umgehen. Halle/S.: Johann Christian Hendel

Riedl-Dorn, C. (1989). The Vienna drawings. In: Norst, M. (ed) Ferdinand Bauer. The Australian natural history drawings, pp.114-116. London, Melbourne, Sydney, Auckland: Lothian $\&$ British Museum of Natural History.

Riedl-Dorn, C. (2019). Ein uomo universale des 19. Jahrhunderts und sein wissenschaftiches Netzwerk - Stephan Ladislaus Endlicher und seine Korrespondenz mit Wissenschaftlern seiner Zeit. Göttingen: V \& R Verlag.

Riedl-Dorn, Köberl, C. \& Stuart, D. (2014). Ferdinand Bauer. Vienna: Verlag des Naturhistorischen Museums Wien.

Schaeffer, J.C. (1769). Entwurf einer allgemeinen Farbenverein oder Versuch und Muster einer gemeinnützlichen Bestimmung und Benennung der Farben. Regensburg: Weiß Emmanuel Adam.

Schiffermüller, I. (1772). Versuch eines Farbensystems. Vienna: Augustin Bernardi.

Schilling, E. (1933). Zu den Zeichnungen Hans Burgkmairs d.Ä. In: Wallraf-RichartzJahrbuch, vol. 7/8, pp. 261-272. Cologne: Freunde des Wallraf-Richartz-Museum und des Museum Ludwig e.V.

Werner, A.G. (1774). Von den äusserlichen Kennzeichen der Fossilien. Leipzig: Crusius.

Willdenow, K.L. (1792). Grundriss der Kräuterkunde. Berlin: Maude \& Spener.

Appendix 1. Collections and unpublished resources used for this paper.

Hamburg Museum für Kunst und Gewerbe, Johann and Joseph Knapp Collection.

Museum of Applied Arts Vienna, Bibliothek und Kunstblättersammlung, Handzeichnungen, Joseph Knapp.

Natural History Museum, London, Bauer Collection.

Natural History Museum Vienna, Archives for the History of Sciences, Bauer Collection now Joseph Knapp “Flora Austriaca”, 7404 98/9.

Natural History Museum Vienna, Archives for the History of Sciences, Bauer Collection now Joseph Knapp “Nestor norfolcensis”, FLB0299.

Natural History Museum Vienna, Archives for the History of Sciences, Theodor Franz Zimmermann "Nestor norfolcensis", TFZB004.

Natural History Museum Vienna, Archives for the History of Sciences, N J. Jacquin Collection Letters Schaeffer to Jacquin.

ÖNB Österreichische Nationalbibliothek, Bildarchiv, Bredemeyer Franz, Joseph Knapp, Flora Exotica Vols I- IV, 1833-1837, Fid ${ }^{\circ} 5904$.

ÖNB Österreichische Nationalbibliothek, Bildarchiv, Joseph Knapp, Obst-, Gemüse- und ZierPflanzenabbildungen, PK485.

Royal Botanic Gardens, Kew, Archives, Letters Fenzl to Bentham 1330-1375.

University of Oxford, Bodleian Library, Flora Graeca, MS Sherard 241-245. 